\title{
Simpanan Karbon pada Ekosistem Padang Lamun di Perairan Jepara
}

\author{
Raka Pramulo Sophianto*, Hadi Endrawati, Retno Hartati \\ Departemen IImu Kelautan, Fakultas Perikanan dan IImu Kelautan, Universitas Diponegoro \\ JI. Prof.H.Soedarto S.H, Tembalang, Semarang, Jawa Tengah 50275 Indonesia \\ ${ }^{*}$ Corresponding author, e-mail : rkpramulo@gmail.com
}

\begin{abstract}
ABSTRAK : Padang lamun merupakan ekosistem yang kompleks dan produktif di ekosistem laut dan pesisir serta salah satu peran utama lamun adalah sebagai penyimpan karbon dengan karakteristik uniknya. Penelitian ini bertujuan untuk mengetahui jenis-jenis lamun, mengetahui struktur komunitas lamun, nilai biomassa dan nilai karbon lamun. Penelitian ini dilakukan pada bulan Oktober dan November 2017 di Teluk Awur dan Pantai Bendengan Jepara. Metode yang digunakan dalam penelitian ini adalah metode deskriptif. Pengambilan sampel dilakukan pada dua tempat masing-masing lima stasiun. Sampel yang diambil adalah lamun, sedimen dan air laut yang ditemukan di lokasi penelitian yang kemudian di identifikasi serta dianalisis di Laboratorium Biologi, Departemen IImu Kelautan, dan analisis pengabuan lamun dilakukan pada di Laboratorium Geologi, Departemen IImu Kelautan, Fakultas Perikanan dan IImu Kelautan, Universitas Diponegoro. Hasil penelitian ini menunjukkan nilai total biomassa lamun yang didapat di kedua lokasi dari sampling pertama yaitu $982,77 \mathrm{gbk} / \mathrm{m}^{2}$ dan sampling kedua yaitu $923,91 \mathrm{gbk} / \mathrm{m}^{2}$. Total kandungan karbon pada sampling pertama berkisar antara $511,76-3662,26 \mathrm{gC} / \mathrm{m}^{2}$ dan total karbon pada sampling kedua berkisar antara $141,48-3344,2 \mathrm{gC} / \mathrm{m}^{2}$. Perbedaan hasil yang di dapat menunjukkan bahwa perbedaan iklim dapat berpengaruh terhadap hasil yang didapatkan.
\end{abstract}

Kata Kunci : Lamun; Biomassa; Karbon; Jepara

\section{Stocks Carbons in Ecosystem Seagrass in Jepara Waters}

ABSTRACT : Seagrass beds are complex and productive ecosystems in marine and coastal ecosystems and one of the main roles of seagrasses is storing carbon with its unique characteristics. This study aims to determine the types of seagrasses, find out the seagrass community structure, biomass values and seagrass carbon values. This research was conducted in October and November 2017 in Teluk Awur and Bendengan Jepara Beach. The method used in this research is descriptive method. Sampling was carried out at two places each of five stations. Samples taken were seagrass, sediments and seawater found at the study site which were then identified and analyzed in the Biology Laboratory, Department of Marine Sciences, and analysis of desertion carried out at the Geology Laboratory, Department of Marine Sciences, Faculty of Fisheries and Marine Sciences, Diponegoro University. The results of this study indicate the total value of seagrass biomass obtained in both locations from the first test was $982.77 \mathrm{gbk} / \mathrm{m}^{2}$ and the second test was $923.91 \mathrm{gbk} / \mathrm{m}^{2}$. The total carbon content in the first sampling ranged from 511.76 $3662.26 \mathrm{gC} / \mathrm{m}^{2}$ and the total carbon in the second sampling ranged from $141.48-3344.2 \mathrm{gC} / \mathrm{m}^{2}$. The difference in results can show that climate differences can affect the results obtained.

Keywords: Seagrass; Biomass; Carbon; Jepara

\section{PENDAHULUAN}

Perubahan iklim akibat emisi gas-gas rumah kaca yang dilepaskan ke atmosfer merupakan isu global yang sudah terjadi sejak lama. Berbagai macam penanggulangan yang telah dilakukan tetap tidak cukup dalam mengurangi gas-gas rumah kaca yang terdapat di atmosfer. Ekosistemekosistem tersebut, yang terdiri dari antara lain hutan mangrove, padang lamun, dan rawa payau, dikenal sebagai Ekosistem Karbon Biru (Herr et al, 2012).

Ekosistem pesisir yang memiliki kemampuan menyerap dan meyimpan karbon dalam kurun waktu yang relatif lama antara lain hutan bakau dan padang lamun. Padang lamun merupakan 
ekosistem yang kompleks dan produktif di ekosistem laut dan pesisir (Green \& Short, 2003). Salah satu peran utama lamun adalah sebagai penyimpan karbon (carbon sink) dengan karakteristik uniknya (Kennedy \& Björk, 2009). Berdasarkan analisis carbon budget (Duarte et al. 2005), pengukuran metabolisme, dan estimasi kapasitas penimbunan karbon (Duarte et al. 2013), komunitas lamun menunjukkan sifat autotrofik sehingga berperan sebagai penyimpan karbon (Duarte et al., 2013).

Lamun memiliki kapasitas yang cukup besar untuk mengakumulasi karbon karena waktu pergantian komponennya yang relatif lambat dan lama. Selain itu, lamun dapat menimbun kelebihan produksi karbon di dalam sedimen yang tersimpan dalam kurun waktu ribuan tahun, misalnya oleh jenis Posedonia oceanica (Mateo et al., 1997), sehingga peran lamun sebagai penyimpan karbon secara proporsional menjadi lebih signifikan dan menjadikan lamun sebagai salah satu ekosistem dengan karbon terkaya di biosfer (Duarte et al., 2011).

Akumulasi karbon di dalam padang lamun diperoleh secara langsung dari fiksasi karbon (fotosintesis) berlebih, sebagian dialokasikan secara langsung ke dalam sedimen sebagai rimpang dan akar (Duarte \& Cebrián, 1996). Sementara itu, karbon organik secara tidak langsung diperoleh dari filtrasi partikel pada kolom air oleh kanopi lamun yang ditambahkan ke dalam sedimen (Hendriks et al., 2008). Padang lamun mendukung sebuah biomassa yang penting, namun biomassa menunjukkan persentase kecil dari cadangan karbon pada padang lamun yang lebih didominasi oleh karbon di dalam sedimen (Duarte et al., 2011).

Teluk Awur dan Pantai Bandengan merupakan yang berada di wilayah administrative Kabupaten Jepara, Jawa Tengah. Teluk Awur dan Pantai Bandengan memiliki kelimpahan padang lamun yang masih cukup baik untuk mengetahui biomassa dan estimasi simpanan karbon.

\section{MATERI DAN METODE}

Materi penelitian yang digunakan adalah sampel lamun yang ditemukan di perairan Teluk Awur dan Pantai Bandengan, Jepara. Penelitian ini dilakukan pada bulan Oktober 2017 sampai Desember 2017. Pada setiap stasiun masing-masing 3 titik kuadran dan 5 titik transek. Tahap selanjutnya yaitu dilakukan Analisa pengukuran biomassa dan karbon pada jaringan lamun yang dilakukan di Laboratorium.

Pengamatan dan pengambilan sampel dilakukan pada siang hari saat keadaan air surut karena akan memudahkan pengamatan serta perhitungan sampel lamun pada jalur serta lokasi yang telah ditentukan. Selain itu juga dilakukan pengambilan data mengenai parameter lingkungan mencakup tipe substrat, suhu, $\mathrm{pH}$ dan salinitas.

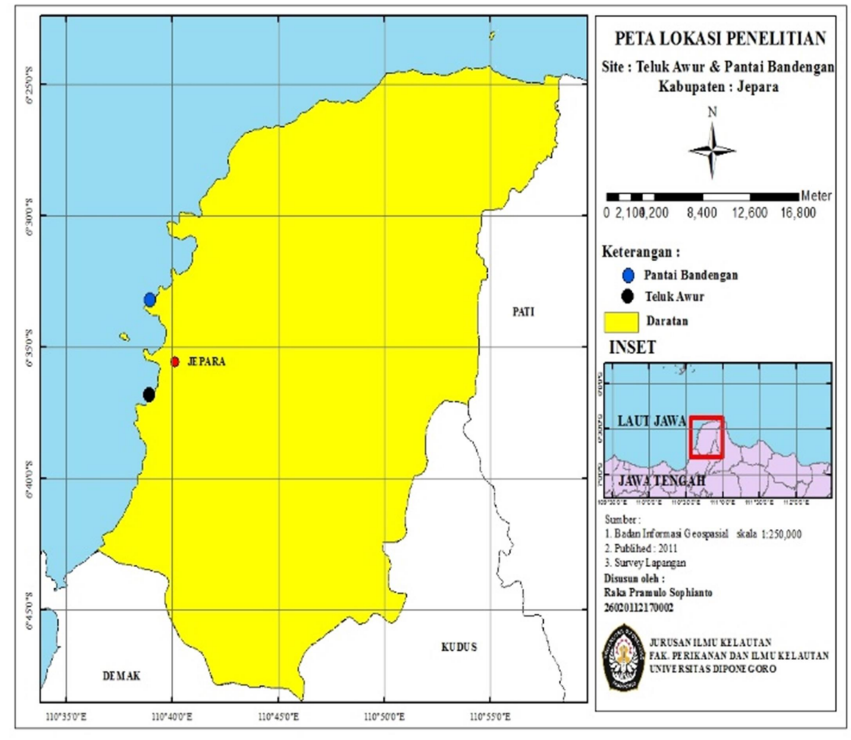

Gambar 1. Peta Stasiun Penelitian 
Pengambilan data parameter dilakukan bersamaan dengan pengambilan sampel lamun, data parameter diambil pada setiap transek. Saat pengambilan sampel perairan berada dalam kondisi surut terendah, sehingga sampel lamun langsung diidentifikasi dan dihitung dalam setiap kuadran pengamatan. Perhitungan sampel dalam kuadran pengamatan, secara tidak langsung juga dapat membantu penerapan nilai-nilai konservasi, dalam hal ini yaitu berkaitan dengan menjaga kelestarian suatu spesies dalam ekosistem.

Pemanenan sampel lamun dilakukan saat pengambilan data lamun, dilakukan juga pemanenan sampel. Sehingga Sampel lamun diambil langsung dengan cara memanen semua lamun yang terdapat di dalam kuadran pengamatan. Hal ini dikarenakan keterbatasan waktu pengambilan, jarak lokasi pengambilan yang cukup jauh dan perubahan pola pasang surut yang cepat mengalami perubahan, mengakibatkan sampel harus dipanen. Sebanyak kurang lebih 25 kuadran yang dipanen lamunnya jika terdapat lamun di titik tersebut. Pemanenan dilakukan dengan cara mencabut setiap individu lamun (beserta rhizom atau akar) dalam kuadran. Setelah pemanenan, sampel diisi ke dalam setiap plastik sampel yang telah diberi label berdasarkan urutan kuadran. Yang diambil hanya sampel lamun, substrat dan biota yang ikut terambil dicuci dan dilepaskan dari sampel. Semua sampel dari lapangan diidentifikasi dan dihitung di rumah.

Setelah pencucian, sampel langsung diidentifikasi, diawetkan dan dihitung. Identifikasi sampel mengacu pada buku Fortes (1990). Pembuatan specimen dilakukan guna mengantisipasi kekeliruan dalam mengidentifikasi. Sampel yang di cuci bersih kemudian di keringkan kemudian memasukkan sampel lamun ke dalam plastik atau toples berukuran sedang atau kecil (sesuai ukuran lamun), lamun yang diawetkan cukup 2-3 individu saja untuk setiap spesies.

Selain pengawetan, sampel juga dihitung berdasarkan spesiesnya, yaitu setiap spesies yang berada dalam semua kuadran pengamatan. Data perhitungan jumlah spesies dipisahkan berdasarkan stasiun yang ada. Data lamun tersebut dianalisis lebih lanjut di Laboratorium.

Penghitungan kerapatan populasi lamun yang ada di perairan Ujung Piring, Jepara digunakan rumus (Azkab, 1999) :

$$
\mathrm{D}=\frac{\mathrm{N}}{\mathrm{A}}
$$

Keterangan : $\mathrm{D}=$ kerapatan populasi $\left(\right.$ tegakan $\left./ \mathrm{m}^{2}\right) ; \mathrm{N}=$ jumlah individu (tegakan); $\mathrm{A}=$ luas daerah pengamatan $\left(\mathrm{m}^{2}\right)$

Penghitungan presentase (\%) penutupan lamun masing-masing spesies didalam transek kuadran berukuran $1 \mathrm{~m} \times 1 \mathrm{~m}$ diberi skor sebagai berikut (English et al., 1994)

$$
\mathrm{C}=\frac{\sum(\mathrm{Mix} \mathrm{Fi})}{\sum \mathrm{f}}
$$

Keterangan : $\mathrm{C}=$ presentase $(\%)$ penutupan lamun; $\mathrm{M}=$ presentase nilai tengah kelas- $\mathrm{I} ; \mathrm{Fi}=$ frekuensi $I ; f=$ frekuensi

Nilai indeks keanekaragaman dengan kriteria sebagai berikut jika $\mathrm{H}^{\prime}<1,0$ menggambarkan sebaran individu tidak merata (keragaman rendah); $1 \leq \mathrm{H}^{\prime} \geq 3,0$ keragaman sedang; $\mathrm{H}^{\prime} \geq 3,0$ keragaman tinggi. Biomassa per tegakan lamun dapat diketahui dengan membagi berat total kering setiap sampel dengan jumlah tegakannya yang dicuplik dan dikalikan dengan jumlah tunas (kepadatan) lamun dalam satu meter persegi. Hubungan antara kerapatan dan biomassa lamun digunakan untuk memprediksi biomassa lamun pada semua titik sampling kepadatan (Gaha, 2015). Rumus yang digunakan untuk menghitung biomassa (Duarte, 1990):

$$
B=W \times D
$$

Keterangan : B = Biomassa Lamun $\left(\mathrm{gram} / \mathrm{m}^{2}\right) ; \mathrm{D}=$ Kepadatan Lamun $\left(\mathrm{m}^{2}\right) ; \mathrm{W}=$ Berat kering sebuah Tunas (gram)

Rumus yang digunakan untuk menghitung kandungan karbon jaringan lamun dengan metode pengabuan sebagai berikut (Helrich, 1990): 


$$
\text { Kadar Abu }=\frac{c-a}{b-a} \times 100 \%
$$

Keterangan : $a=$ Berat cawan; $b=$ Berat cawan + berat kering jaringan lamun; $c=$ Berat cawan + berat abu jaringan lamun

Bahan organik dihitung dengan metode pengabuan ini dapat ditentukan dengan menghitung pengurangan berat saat pengabuan, yaitu sebagai berikut (Helrich, 1990):

$$
\text { Kadar Bahan Organik }=\frac{[(b-a)-(c-a)]}{(b-a)} \times 100 \%
$$

Keterangan $: a=$ Berat cawan; $b=$ Berat cawan + berat sampel; $c=$ Berat $($ cawan + abu $)$

Setelah mengetahui kadar bahan organik, dilakukan penghitungan kandungan karbon jaringan lamun dengan metode pengabuan yaitu sebagai berikut (Helrich, 1990):

Keterangan : 1,724 $=$ konstanta nilai bahan organik

$$
\text { KandunganKarbon }=\frac{\text { Kadar Bahan Organik }}{1,724}
$$

Perhitungan total stok karbon lamun di lokasi penelitian dianalisis dengan menggunakan konversi data biomassa menjadi kandungan karbon yang didapatkan pada awal penelitian. Data hasil konversi ke karbon keseluruhan kemudian dirata-rata dengan $\mathrm{gC} / \mathrm{m}^{2}$. Setelah mendapatkan nilai rata-rata karbon per meter persegi kemudian dikalikan dengan luas lamun yang ada dilokasi penelitian. Total stok karbon lamun dihitung dengan menggunakan rumus menurut Sulaeman et al. (2005):

$$
\mathrm{Ct}=\Sigma(\mathrm{Li} \times \mathrm{Ci})
$$

Keterangan : $\mathrm{Ct}=$ karbon total (ton); $\mathrm{Li}=$ luas padang lamun kategori kelas $\mathrm{I}\left(\mathrm{m}^{2}\right) ; \mathrm{Ci}=$ rata-rata stok karbon lamun kategori kelas I $\left(\mathrm{gC} / \mathrm{m}^{2}\right)$

\section{HASIL DAN PEMBAHASAN}

Ekosistem lamun di perairan Bandengan ini memiliki 5 jenis lamun yaitu Cymodocea serrulate, C. rotundata, Thalassia hemprichii, Enhalus acoroides, Halodule uninervis. Sedangkan di perairan Teluk Awur terdapat 5 jenis lamun yaitu yaitu C. rotundata, C. serrulata, T. hemprichii, E. acoroides, Syringodium isoetifolium. Hasil juga menunjukan bahwa C. serrulata dan $T$. hemprichii merupakan spesies yang paling banyak ditemukan di kedua lokasi. Pada umumnya yang hidup di Perairan Teluk Awur dan Pantai Bandengan merupakan jenis lamun yang hidup di perairan dangkal dan selalu mudah ditemukan saat air laut surut.

Kerapatan lamun dan persentase tutupannya pada dua kali pengambilan sampel di Perairan Teluk Awur dan Pantai Bandengan yang disajikan dalam Tabel 1. Pada Perairan Teluk Awur yang tertinggi yaitu pada Line ke tiga, sedangkan pada Perairan Pantai Bandengan yang teringgi yaitu pada Line ke satu. Kondisi kerapatan lamun di padang lamun perairan Teluk Awur dan pantai Prawean Bandengan, Jepara, dapat dikatakan masih relatife baik (Riniatsih et al., 20019). Pertumbuhan, perkembangan serta kerapatan lamun dipengaruhi oleh faktor-faktor fisika dan kimia perairan seperti kedalaman, kecerahan, kuat arus serta ketersediaan bahan organik. Keberadaan lamun bukan hanya sebagai salah satu penyedia oksigen terlarut di dalam perairan, namun juga merupakan habitat dan daerah untuk mencari makanan bagi banyak jenis biota laut. Selain itu lamun juga berfungsi sebagai perangkap sedimen yang dapat mencegah abrasi. Daun lamun yang lebat akan memperlambat air yang disebabkan oleh ombak dan arus, sehingga perairan sekitarnya akan menjadi lebih tenang. Hal ini juga berkaitan dengan kerapatan dari lamun di suatu perairan, semakin rapat lamun diperairan tersebut maka akan makin tenang perairan tersebut (Hartati et al., 2012).

Penutupan lamun berkisar 14-36,33\% di perairan Teluk Awur dan di Bandengan 43,67$62,33 \%$. Secara keseluruhan, kerapatan dan penutupan lamun pada di kedua lokasi penelitian, sampel bulan Juni lebih tinggi dibandingkan bulan Oktober 2017 (Tabel 1). Penutupan lamun 
berhubungan erat dengan morfologi dan ukuran suatu spesies lamun. Satu individu E. acoroides akan memiliki nilai penutupan yang lebih tinggi dibandingkan dengan satu individu $H$. uninervis karena ukuran daun Enhalus yang jauh lebih besar. Sedangkan individu lamun yang berukuran lebih kecil seperti Halophila akan memiliki nilai persentase penutupan yang lebih kecil pula (Short dan Coles, 2001).

Nilai biomassa lamun pada bulan Juni 2017 dan Oktober 2017 di Perairan Teluk Awur dan Perairan Pantai Bandengan masing-masing ditampilkan Gambar 2 dan 3. Nilai biomassa lamun Oktober 2017 di Perairan Teluk Awur dan Perairan Pantai Bandengan dipengaruhi oleh ketersedian nutrien di perairan dan musim, karena bulan Oktober mulai turun hujan. Menurut Laffoley dan Grimsditch (2009), jenis lamun yang secara morfologi berukuran besar cenderung mengembangkan biomassa yang tinggi. E. acoroides memiliki morfologi yang paling besar diantara spesies lamun lainnya, sehingga diduga $E$. acoroides sebagai penyumbang biomassa yang tinggi. Selain itu biomassa bagian bawah lebih tinggi karena rhizoma mengandung banyak zat pati dan unsur hara dimana zat tersebut didistribusikan dari hasil fotosintesis yang disimpan pada bagian dibawah substrat, sehingga biomassa pada rhizoma dibawah substrat lebih tinggi

Tabel 1. Kerapatan (ind $/ \mathrm{m}^{2}$ ) dan Penutupan (\%) Lamun di Semua stasiun di perairan Teluk Awur dan Bandengan, Jepara

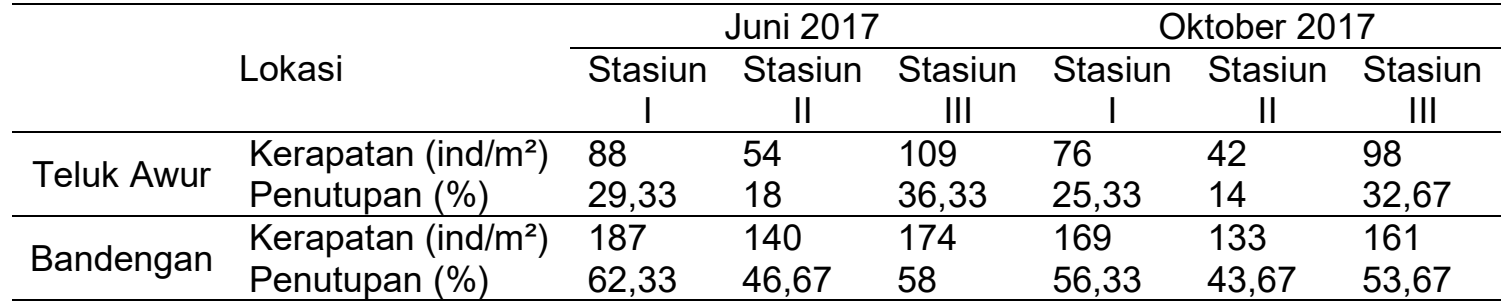

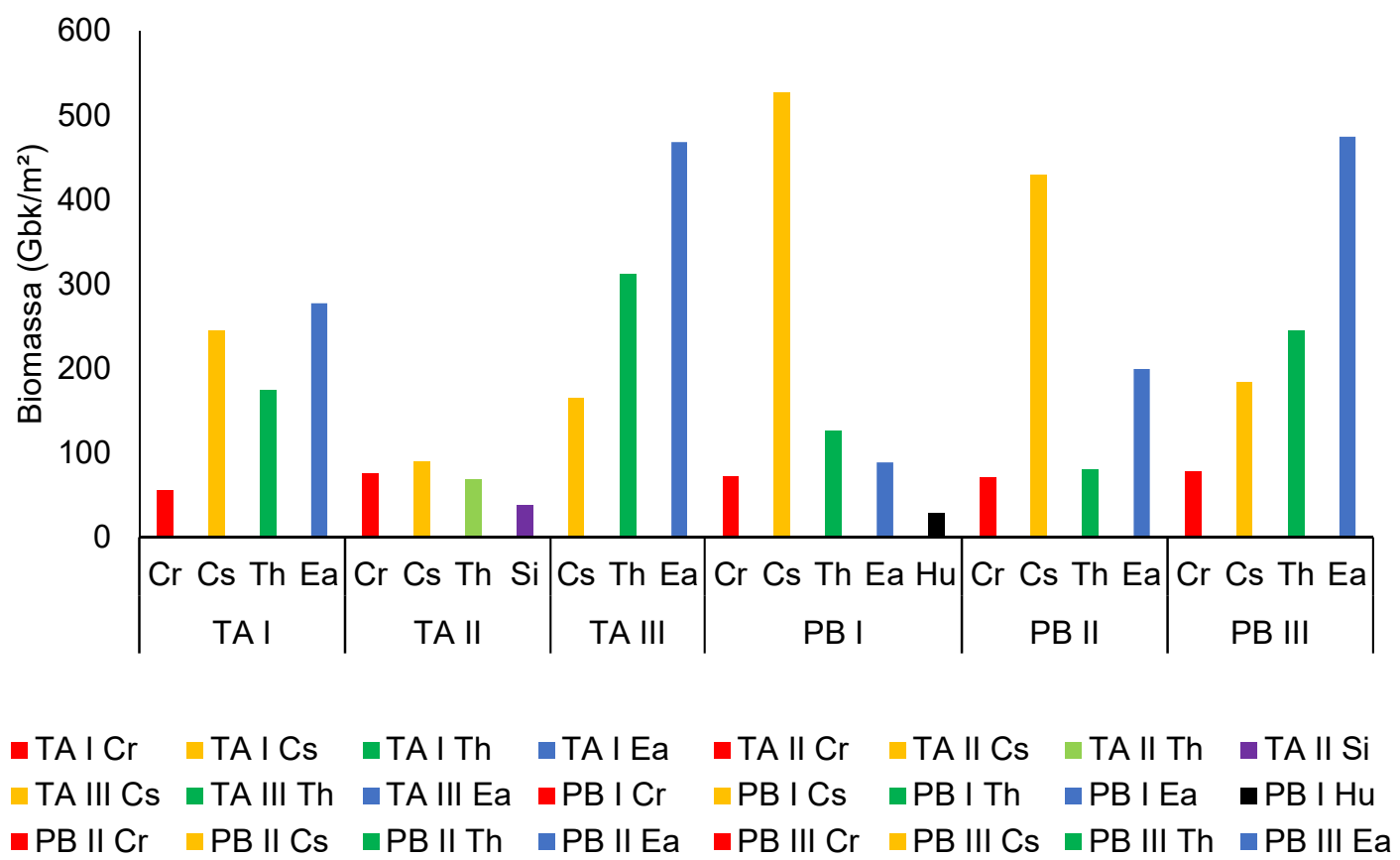

Gambar 1. Biomassa Lamun di perairan Teluk Awur dan Pantai Bandengan pada Bulan Juni 2017 


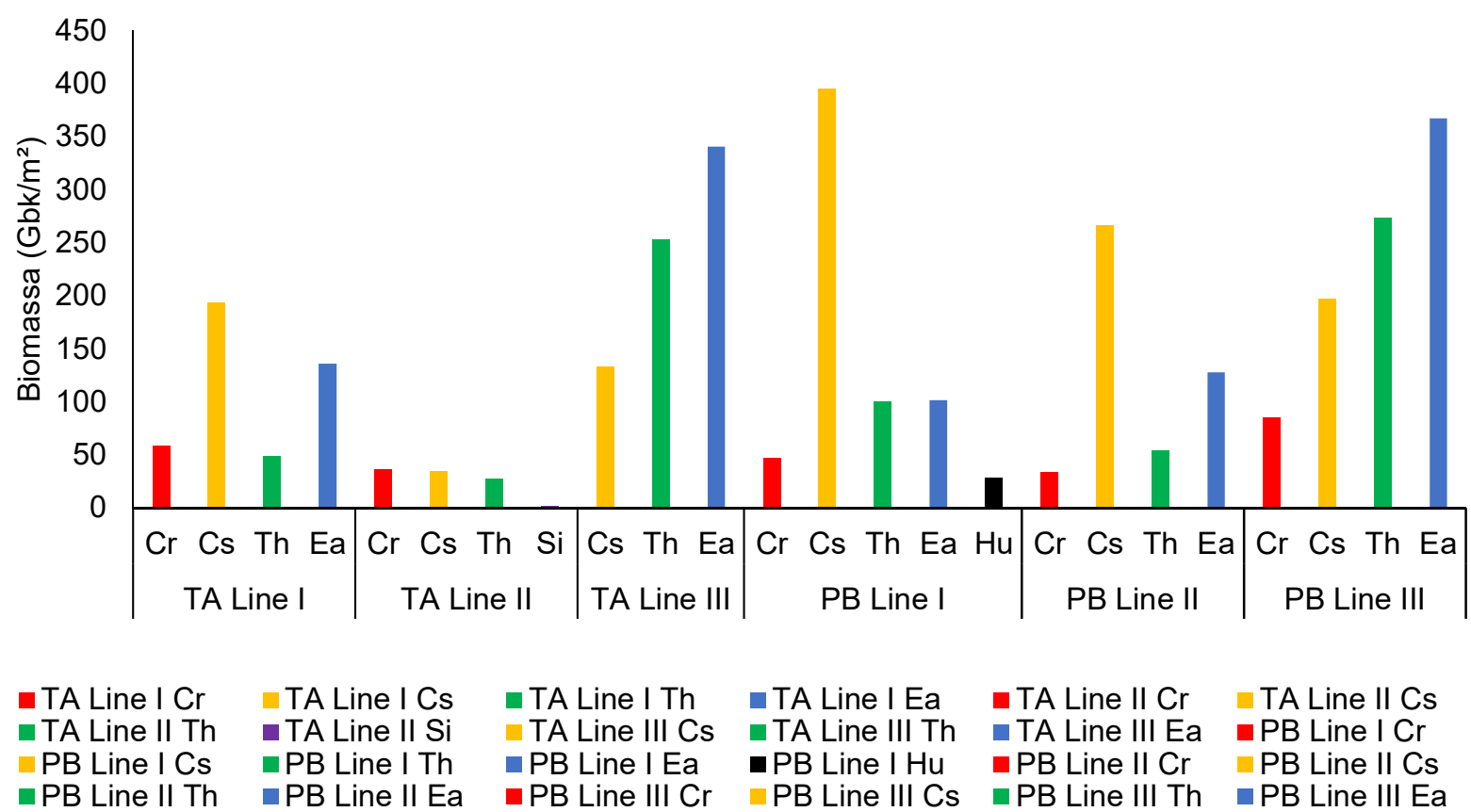

Gambar 2. Biomassa Lamun di perairan Teluk Awur dan Pantai Bandengan pada Bulan Oktober 2017

dibandingkan dengan jaringan lainnya (Hartati et al., 2017b). Menurut Al-bader et al. (2014) semakin banyak rimpang dan akar yang dapat menembus sedimen maka akar dapat menciptakan ruang pori pada substrat yang kemudian yang akan membantu dalam penyimpanan nutrient serta pemasukan nutrisi pada rimpang juga substrat.

\section{Estimasi Karbon pada Lamun}

Menurut Ulumuddin (2005) stok karbon merupakan kandungan karbon absolut yang disimpan dalam biomassa tumbuhan pada waktu tertentu. Kandungan karbon dimana akan sejalan dengan nilai kandungan biomassa pada tumbuhan. Akan diperoleh hasil analisa karbon yang dilakukan pada jaringan (daun, rhizome dan akar) lamun dengan metode pengabuan. Berdasarkan hasil penelitian ini, nilai stok karbon terbesar pada sampling pertama (Juni 2017) terdapat di perairan Bandengan, yaitu pada C. serullata (3667,26 \%C), sedangkan pada sampling Oktober 2017 terdapat di perairan Pantai Bandengan pada jenis lamun C. serullata dan dengan nilai $3344,2 \%$ C. Di perairan Teluk Awur nilai estimasi stok karbon pada bulan Juni 2017 pada lamun S. isoetifolium (531,58 \%C) lebih tinggi daripada Oktober 2017 pada jenis lamun yang sama (S. isoetifolium) sebesar 141,48 \%C. Menurut Graha (2015) menyatakan bahwa variasi kandungan karbon lamun dipengaruhi oleh perbedaan biomassa antar jenis ataupun antar jaringan. Semakin tinggi kandungan biomassa pada lamun maka nilai kandungan karbon pada jaringan lamun juga semakin meningkat dimana artinya kandungan karbon berbanding lurus dengan kandungan biomassa pada lamun (Hendriks et al., 2008). Menurut Kennedy et al. (2010) karbon organik yang dihasilkan oleh lamun tidak hanya didapatkan dari hasil tanaman dan sumber dari satu lokasi saja tetapi dapat juga diperoleh dari nutrient yang terbawa oleh arus melalui berbagai peristiwa, misalkan pergerakan massa air, ombak dan arus dari tempat lainnya,

Nilai kandungan karbon pada Bulan Juni 2017 yang terdapat bagian bawah substrat berkisar antara $260,96-3346,98 \mathrm{gC} / \mathrm{m}^{2}$ atau $6,14-9,88$ ton atau lebih besar dibandingkan dengan kandungan karbon pada bagian atas substrat yang berkisar antara $174-1332,6 \mathrm{gC} / \mathrm{m}^{2}$ atau 3.294,40 ton (Tabel 2). Sedangkan nilai kandungan karbon pada Oktober 2017 yang terdapat bagian bawah substrat berkisar 42,06-2104,03 $\mathrm{gC} / \mathrm{m}^{2}$ (5,27-7,53 ton) lebih besar dibandingkan dengan 
kandungan karbon pada bagian atas substrat yang berkisar antara 99,42-1240,17 gC/m ${ }^{2}$ atau 8,15-11,63 ton. Hal ini dikarenakan kandungan karbon dibawah substrat tidak terlalu terkena pengaruh oleh faktor fisik lingkungan dibandingkan dengan kandungan karbon yang terdapat pada bagian atas substrat yang lebih dipengaruhi oleh faktor perairan seperti suhu dan lainnya (Rahman et al., 2014). Kennedy et al. (2010) menyatakan bahwa kandungan karbon dibawah substrat akan tersimpan disedimen walaupun tunas pada lamun tersebut telah mati, sedangkan karbon diatas substrat hanya akan tersimpan jika tunas lamun masih tetap hidup.

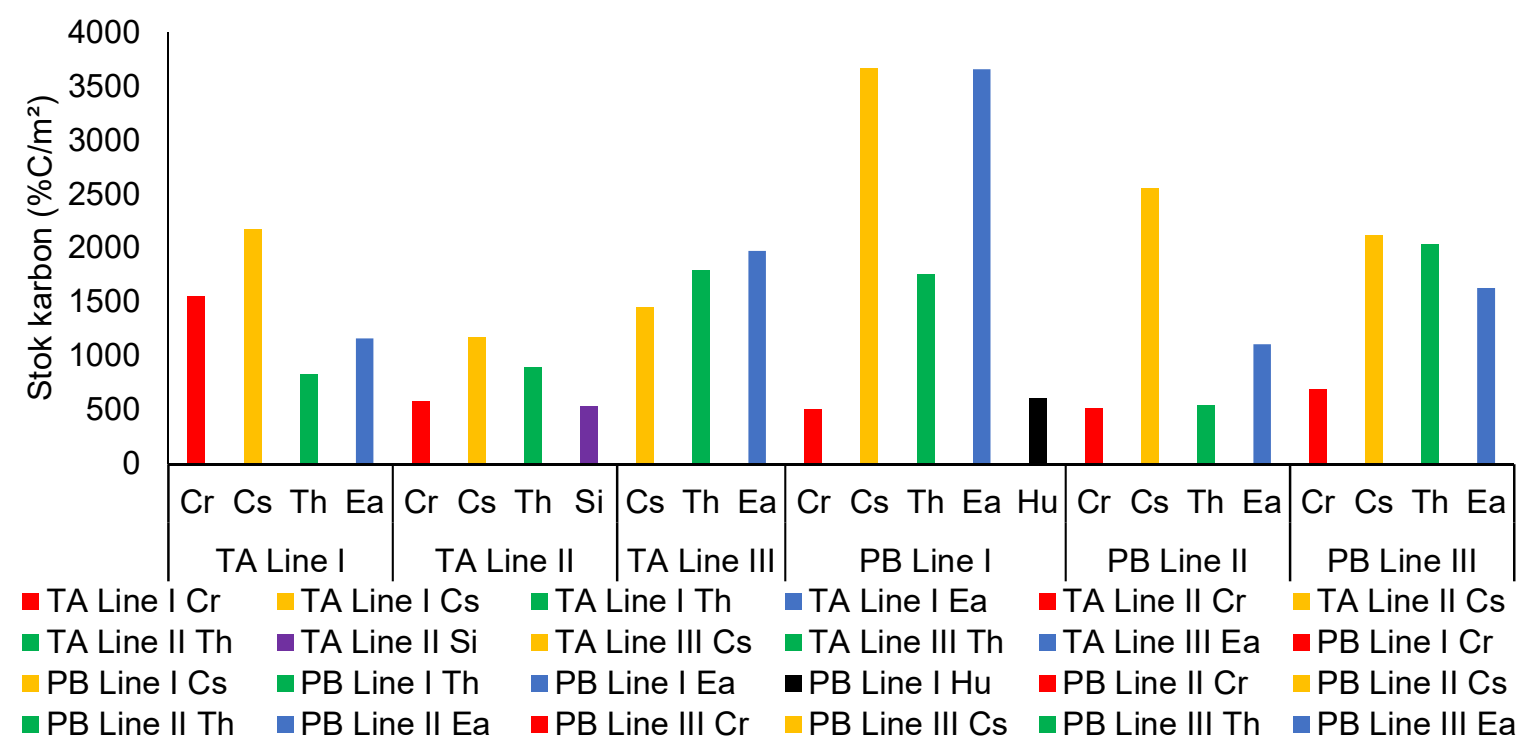

Gambar 3. Nilai stok karbon di perairan Teluk Awur dan Pantai Bandengan pada Bulan Oktober 2017

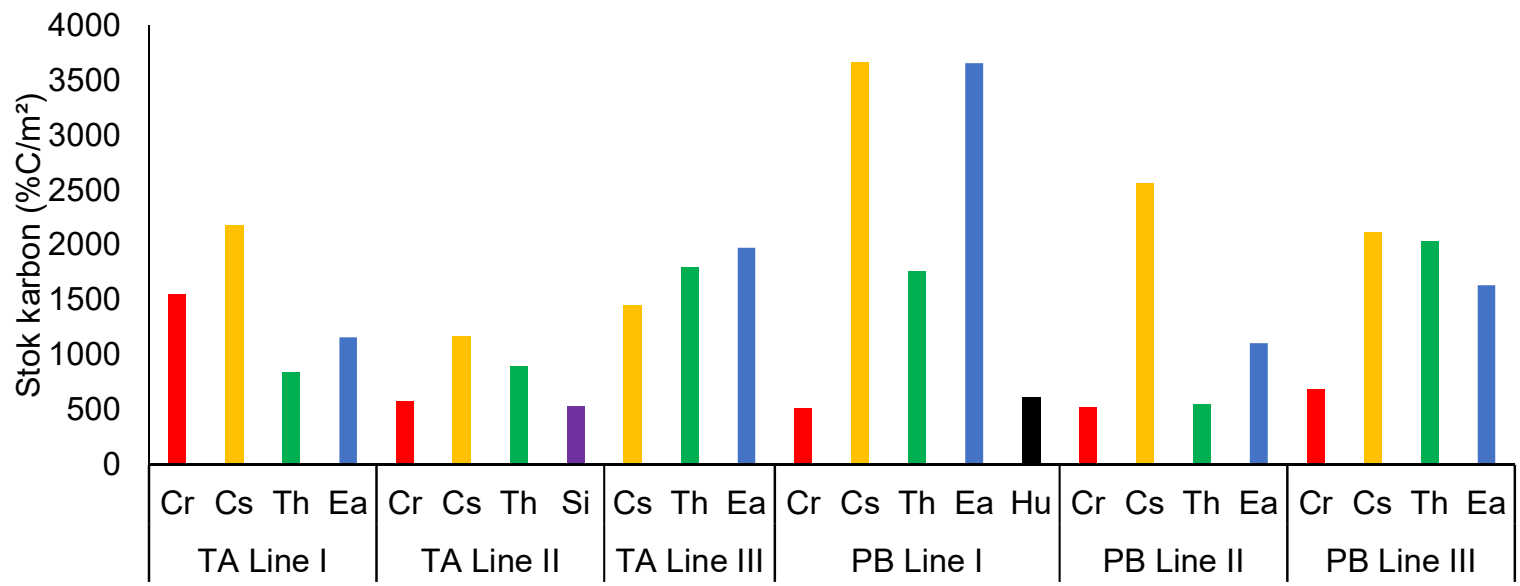

\begin{tabular}{|c|c|c|c|c|c|}
\hline TA L & $\square \mathrm{TA}$ & TA & & & \\
\hline & & & - TA L & & \\
\hline & - PB & & & & \\
\hline & PB Line II & PB Line II & PB Line I & 口B Line II & 3 Line \\
\hline
\end{tabular}

Gambar 4. Nilai stok karbon di perairan Teluk Awur dan Pantai Bandengan pada Bulan Juni 2017 
Tabel 2. Perbandingan Nilai Estimasi Stok Karbon pada bulan Juni dan Oktober 2017

\begin{tabular}{ccccc}
\hline & \multicolumn{2}{c}{ Teluk Awur } & \multicolumn{2}{c}{ Bandengan } \\
\cline { 2 - 5 } Jaringan & Juni 2017 & Oktober 2017 & Juni 2017 & Oktober 2017 \\
\hline Bawah (ton) & 6,14 & 5,27 & 9,88 & 7,53 \\
Atas (ton) & 3,29 & 2,88 & 4,40 & 4,10 \\
\hline Jumlah & 9,43 & 8,15 & 14,28 & 11,63 \\
\hline
\end{tabular}

Parameter kualitas perairan merupakan faktor penting dalam kelangsungan kehidupan biota atau organisme di suatu perairan laut. Kondisi perairan sangat menentukan kelimpahan dan penyebaran lamun, akan tetapi lamun memiliki kebutuhan dan preferensi lingkungan yang berbeda untuk hidup yang terkait dengan karakteristik lingkungannya (Tomascick et al., 1997). Kisaran nilai parameter kualitas air di ekosistem lamun Perairan Teluk Awur dan Bandengan, Kabupaten Jepara disajikan pada Tabel 3. Berdasarkan baku mutu KepMenLH No. 51 Tahun 2004 nilainya masih layak dan baik untuk kehidupan lamun.

Tabel 3. Kisaran nilai parameter kualitas air di ekosistem lamun Perairan Teluk Awur dan Bandengan, Kabupaten Jepara

\begin{tabular}{cccc}
\hline Parameter & Teluk Awur & Bandengan & Baku Mutu *) \\
\hline Kedalaman (cm) & $60-300$ & $30-300$ & - \\
Kecerahan (cm) & $60-300$ & $30-300$ & $>3 \mathrm{~m}$ \\
Suhu (c) & $30,5-31,2$ & $31,3-31,4$ & $28-30$ \\
Arus (m/s) & $0,05-0,06$ & $0,01-0,05$ & - \\
Salinitas (ppt) & $29-32$ & $29-33$ & $33-34$ \\
Do (mg/L) & $4,1-4,6$ & $4,67-7,23$ & $>5$ \\
pH & $7,2-7,66$ & $7,8=8,0$ & $7-8,5$ \\
\hline
\end{tabular}

Sumber : *) KepMenLH No. 51 Tahun 2004

\section{KESIMPULAN}

Pada ekosistem lamun di perairan Teluk Awur dan Bandengan, Jepara terdapat 6 spesies, yaitu Cymodocea serrulata, C. rotundata, Thalassia hemprichii, Enhalus acoroides, Halodule uninervis dan Syringodium isoetifolium. Kerapatan lamun tertinggi pada bulan Juni 2017 di stasiun Perairan Teluk Awur, pada Stasiun $3\left(98 \mathrm{ind} / \mathrm{m}^{2}\right)$ dengan tutupan 32,67\% dan lamun jarang ditemukan yaitu pada Stasiun 2 (42 ind $/ \mathrm{m}^{2}$ ) dengan tutupan $14 \%$. Pada waktu yang sama di Perairan Bandengan lamun paling banyak ditemukan pada Stasiun $1\left(169 \mathrm{ind} / \mathrm{m}^{2}\right)$ dengan tutupan 56,33\% dan lamun jarang ditemukan pada Stasiun 2 sebanyak $133 \mathrm{ind} / \mathrm{m}^{2}$ dengan tutupan 43,67\%. Biomassa lamun tertinggi terdapat pada bulan Juni 2017 di bawah substrat $\left(17,82-295,86 \mathrm{gbk} / \mathrm{m}^{2}\right)$. Nilai karbon tertinggi juga terdapat pada bulan Juni 2017 pada bagian bawah substrat $(260,96-$ $3346,98 \mathrm{gC} / \mathrm{m}^{2}$ ) lebih besar dibandingkan dengan kandungan karbon pada bagian atas substrat yang berkisar $174-1332,6 \mathrm{gC} / \mathrm{m}^{2}$

\section{UCAPAN TERIMAKASIH}

Artikel ini merupakan bagian dari skripsi yang berjudul "Biomassa dan estimasi simpanan karbon pada ekosistem padang lamun di perairan Teluk Awur dan Pantai Bandengan Kabupaten 
Jepara" untuk memperoleh gelar Sarjana Strata Satu Program Studi IImu Kelautan, Fakultas Perikanan dan IImu Kelautan, Universitas Diponegoro.

\section{DAFTAR PUSTAKA}

Al-Bader, D.A., Shuail, D.A., Al-Hasan, R. \& Suleman, P. 2014. Intertidal seagrass Halodule uninervis: Factors controlling its density, biomass, and shoot length. Kuwait J. Sci. 41(A):1-14.

Arlington, USA, Gland, Switzerland, p. 39.

Azkab, M.H. 1999. Pedoman Invetarisasi lamun, Oseana, IV (1):1-16 hal.

Duarte CM., Middelburg, J.J., \& Caraco, N. 2005. Major role of marine vegetation on the oceanic carbon cycle. Biogeosciences, 1:173-180.

Duarte, C.M., Kennedy, H., Marba, N. \& Hendriks, I. 2011. Assessing the capacity of seagrass meadows for carbon burial: current limitations and future strategies. Ocean \& Coastal Management, 83:32-38. DOI : 10.1016/j.ocecoaman.2011.09.001.

Duarte, C.M., Sintes, T. \& Marb, N. 2013. Assessing the $\mathrm{CO}_{2}$ capture potential of seagrass restoration projects. Journal of Applied Ecology 50:1341-1349

English, S., Wilkinson, C., \& Baker, V. 1994. Survey Manual for Tropical Marine Resources. Australian Institute of Marine Science. Townsville. Australia.

Graha, Y.I. 2015. Simpanan Karbon Padang Lamun di Kawasan Pantai Sanur, Kota Denpasar. [Thesis]. Program Pascasarjana, Universitas Udayana, Bali.

Green, E.P. \& Short, F.T. (eds.). 2003. World Atlas of Seagrasses. University of California Press, Berkeley, USA. 324 pp.

Hartati, R., Pratikto, I., \& Pratiwi, T.N. 2017b. Biomassa dan Estimasi Simpanan Karbon pada Ekosistem Padang Lamun di Pulau Menjangan Kecil dan Pulau Sintok, Kepulauan Karimunjawa. Buletin Oseanografi Marina, 1:7481

Hartati, R., Djunaedi, A., Hariyadi, \& Mujiyanto. 2012. Struktur Komunitas Padang Lamun di Perairan Pulau Kumbang, Kepulauan Karimunjawa. IImu Kelautan, 17(4): 217-225

Hartati, R., Trianto, A. \& Widianingsih. 2017a. Habitat characteristic of two selected locations for sea cucumber ranching purposes. IOP Conf. Series: Earth and Environmental Science 55:012041. doi: 10.1088/1755-1315/55/1/012041

Helrich, K.C.(Ed.). 1990. Official methods of Analysis of the AOAC. Vol. 2. No.Ed. 151298 pp

Hendriks, I.E., Sintes, T., Bouma, T.J. \& Duarte, C.M., 2008. Experimental assessment and modeling evaluation of the effects of seagrass (Posidonia oceanica) on flow and particle trapping. Mar. Ecol. Prog. Ser. 356:163-173

Herr, D., Pidgeon, E. \& Laffoley, D., 2012. Blue Carbon Policy Framework: Based on the Discussion of the International Blue Carbon Policy Working Group. IUCN and

Kemetrian Lingkungan Hidup. 2004. Keputusan Menteri Lingkungan Hidup Nomor 51 Tahun 2004 tentang Baku Mutu Air Laut. Jakarta: Kementrian Lingkungan Hidup. 5 hlm.

Kennedy, H. \& Björk, M. 2009. Seagrass Meadows. In: Laffoley D, Grimsditch G (eds.). The management of natural coastal carbon sinks. IUCN, Gland, Switzerland

Kennedy, H., Holmer, M., Beggins, J., Marbà, N., Duarte, C.M., Fourqurean, J.W., \& Middelburg, J.J. 2010. Seagrass sediments as a global carbon sink: Isotopic constraints. Global Biogeochemical Cycles, 24(GB4026): 1-8. DOI :10.1029/2010GB003848

Laffoley, D. \& Grimsditch, G. 2009. The Management of Natural Coastal Carbon Sinks. IUCN, Gland Switzerland.

Mateo, M.A. \& Romero, J. 1997. Detritus dynamics in the seagrass Posidonia oceanica: elements for an ecosystem carbon and nutrient budget. Mar. Ecol. Prog. Ser. 151: 43-53,

Rahman, F.A., Qayim, I. \& Wardiatno, Y. 2014. Carbon storage variability in seagrass meadows of Marine Poton Bako, East Lombok, West Nusa Tenggara, Indonesia. Biodiversitas, 19(5): 1626-1631 DOI: 10.13057/biodiv/d190505

Riniatsih, I., Ambariyanto, A., Yudiati, E., Hartati, R., Widianingsih \& Mahendrajaya, R.T.. 2019. Diversity species and condition of seagrass ecosystem in Teluk Awur and Prawean Jepara. IOP Conf. Series: Earth and Environmental Science, 236:012052. DOI : 10.1088/1755$1315 / 236 / 1 / 012052$ 
Short, F.T. \& Coles, R. 2001. Global Seagrass Research Methods. Elsevier Publishing, The Netherlands, $482 \mathrm{pp}$

Sulaeman, Suparto \& Eviati. 2005. Petunjuk Teknis Analisis Tanah, Tanaman, Air dan Pupuk. Balai Penelitian Tanah, Badan Penelitian dan Pengembangan Pertanian, Departemen Pertanian, Bogor.

Tomascick, T., Mah, A.J., Nontji, A., \& Moosa, K. 1997. The Ecology of the Indonesia Seas. Part One. Periplus Edition (HK) Ltd., Singapore 